\title{
Marine Objects Recognition Using Convolutional Neural Networks
}

\section{Prepoznavanje morskih objekata uporabom konvolucijskih neuronskih mreža}

\author{
Ivan Lorencin \\ University of Rijeka \\ Faculty of Engineering \\ e-mail: ilorencin@riteh.hr
}

\author{
Nikola Anđelić \\ University of Rijeka \\ Faculty of Engineering \\ e-mail: nandelic@riteh.hr
}

\author{
Vedran Mrzljak \\ University of Rijeka \\ Faculty of Engineering \\ e-mail:vmrzljak@riteh.hr
}

\author{
Zlatan Car \\ University of Rijeka \\ Faculty of Engineering \\ e-mail: car@riteh.hr
}

DOI 10.17818/NM/2019/3.3

UDK 004.89:629.5

Preliminary communication / Prethodno priopćenje

Paper accepted / Rukopis primljen: 24. 4. 2019.

\section{Summary}

One of the challenges of maritime affairs is automatic object recognition from aerial imagery. This can be achieved by utilizing a Convolutional Neural Network (CNN) based algorithm. For purposes of these research a dataset of 5608 marine object images is collected by using Google satellite imagery and Google Image Search. The dataset is divided in two main classes ("Vessels" and "Other objects") and each class is divided into four sub-classes ("Vessels" sub-classes are "Cargo ships", "Cruise ships", "War ships" and "Boats", while "Other objects" sub-classes are "Waves", "Marine animals", "Garbage patches" and "Oil spills"). For recognition of marine objects, an algorithm constructed with three CNNs is proposed. The first CNN for classification on the main classes achieves accuracy of $\mathbf{9 2 . 3 7} \%$. The CNN used for vessels recognition achieves accuracies of $94.12 \%$ for cargo ships recognition, $98.82 \%$ for cruise ships recognition, $\mathbf{9 7 . 6 4} \%$ for war ships recognition and $\mathbf{9 5 . 2 9} \%$ for boats recognition. The CNN used for recognition of other objects achieves accuracies of $88.56 \%$ for waves and marine animals recognition, $96.92 \%$ for garbage patches recognition and $89.21 \%$ for oil spills recognition. This research has shown that CNN is appropriate artificial intelligence (AI) method for marine object recognition from aerial imagery.

\section{Sažetak}

Jedan je od izazova u pomorstvu automatsko prepoznavanje objekata na zračnim snimkama. Ono se može postići uporabom algoritma na temelju konvolucijskih neuronskih mreža (CNN). U ovome istraživanju prikupljeni su podaci na temelju 5608 slika morskih objekata dobivenih s pomoću Googleovih satelitskih snimaka i pretraživanja slika. Prikupljeni podaci podijeljeni su na dvije kategorije (,Brodovi“ $i$ "Ostali objekti"), a svaka kategorija podijeljena je na četiri potkategorije (potkategorije "Brodova" jesu "Teretni brodovi", "Brodovi za kružna putovanja", "Ratni brodovi" $i$ "Brodice", dok su potkategorije "Ostalih objekata" "Valovi", "Morska bića", "Otoci smeća" $i$ "Izljevi nafte"). Da bi se prepoznali morski objekti, predložen je algoritam koji se sastoji od triju konvolucijskih neuronskih mreža (CNN). Preciznost prvog CNN-a kojim se klasificiraju osnovne kategorije iznosi otprilike 98,82\%. Preciznost CNN-a kojim se prepoznaju brodovi iznosi 94,12\% za teretne brodove, 98,22\% za kruzere, 97,64\% za ratne brodove i 95,29\% za brodice. Preciznost CNN mreža koje se koriste za prepoznavanje drugih objekata iznosi otprilike $88,56 \%$ za valove i morska bića, $96,92 \%$ za prepoznavanje otoka smeća te $89,21 \%$ za prepoznavanje izljeva nafte. Rezultati istraživanja pokazali su da su CNN mreže odgovarajuća metoda umjetne inteligencije (Al) za prepoznavanje morskih objekata na zračnim snimkama.

\section{KEY WORDS}

artificial intelligence Convolutional Neural Network marine object recognition vessels pollution

\section{INTRODUCTION / Uvod}

With the ever-rising trend of drones [1] [2] and satellite imagery usage for aerial surveillance [3] [4], a high possibility of applying these technologies to sea and coastal surveillance can be noticed. As another possibility, the application of the Al algorithm in aerial surveillance of the sea and coastal areas is imposed. One of the key challenges in the sea and costal area aerial surveillance is the protection of endangered animals.
Human influence is one of the leading causes of death among the population of Bottlenose Dolphin (Tursiops truncates) [5]. For these reasons it is crucial to limit maritime traffic and fishing in areas where these animals are present. Similar is the case of Mediterranean monk seal (Monachus monachus) [6]. Limiting the human activity in areas where endangered species are present can possibly decrease the number of deaths that are 
caused by human activity. One way to limit the human activity is to detect endangered animals in real time and redirect activities to another location. This could be achieved by utilizing Al algorithms. Al could be applied to pollution preventing (or pollution reduction) [7], [8], fuel consumption optimization [9], port management, etc. Al approach can also be used in the control and optimization of various marine components [10] or the entire marine systems [11]. From the point of view of maritime traffic safety, artificial intelligence can be used to identify vessels and weather conditions.

\section{RELATED WORK / Pregled dosadašnjih istraživanja}

In recent years, image recognition techniques have become commonly used techniques in a wide spectrum of science and technology [12] [13]. Image recognition techniques are used in fields of medicine [14] [15], agriculture [16] [17], traffic [18] etc. The most used $\mathrm{Al}$ algorithm for tasks of image recognition and computer vision is CNN [19]. Recent researches are presenting methods for ship detection using CNN. In [20] four different CNN architectures are utilized for ship classification. Aforementioned CNNs are designed by varying convolutional, pooling and fully connected layers design. With this approach, accuracy of $82 \%$ is achieved. In [21] CNN-based algorithm for automatic ship detection is proposed. In this case, accuracy higher than $90 \%$ is achieved. In [22] an algorithm for marine organism classification is proposed. By utilizing CNN, accuracy of $92 \%$ is achieved. Described approaches are offering narrower classification of marine objects.

From described possibilities, three questions arise.

Is the CNN appropriate algorithm for marine object recognition?

Is there a possibility to realize a CNN-based algorithm for recognizing vessel type, marine animals, waves and pollution?

Is it possible to utilize a universal algorithm for recognition of all objects?

In this paper a universal CNN-based algorithm for recognition of various marine objects is described. At first, used dataset is described. After that, the algorithm for marine objects recognition is described. The algorithm is trained and tested using training and testing datasets.

\section{MATERIALS AND METHODS / Materijali i metode 3.1. Dataset description / Opis prikupljenih podataka} The dataset used in this research is constructed by using Google satellite images [23] and images collected from Google Image Search. All images are obtained by screenshotting area that represents the object of interest. Obtained images are then resized to $200 \times 200$ pixels size by using Open Source Computer Vision Library (OpenCV). Collected images are divided into two main classes: class which represents vessels and class which represents other objects. The "Vessels" main class is divided into four sub-classes: "Cargo ships", "Cruise ships", "War ships" and "Boats". Examples of these sub-classes are shown in Figure 1.

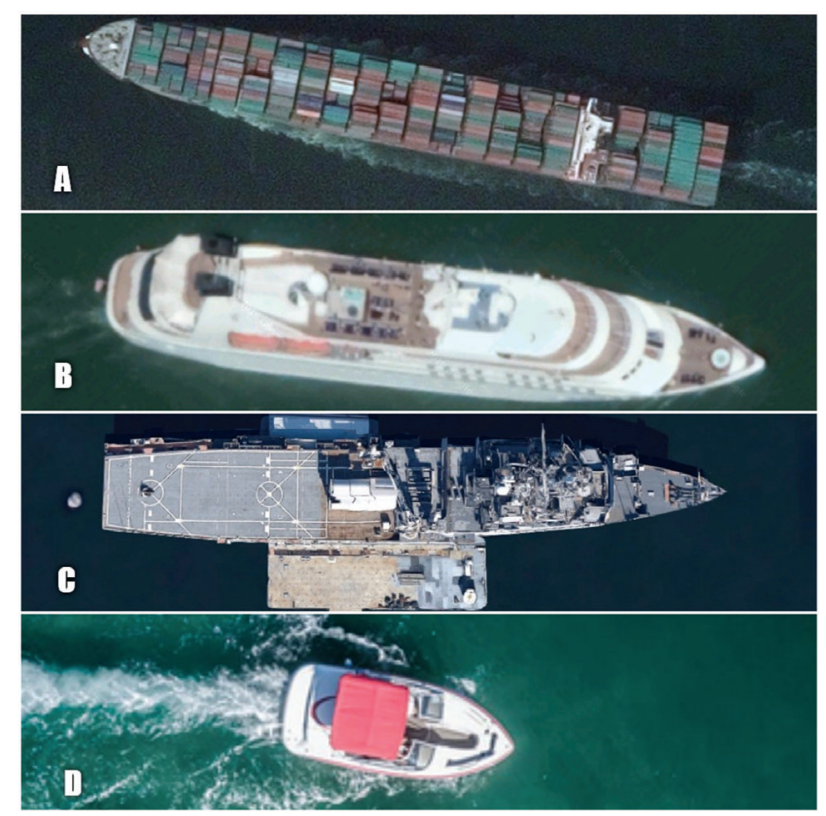

Figure 1 Examples of images that represent "Vessels" main class (A - Cargo ships, B - Cruise ships, C - War ships and D - Boats) [23]

Slika 1. Primjeri slika osnovne kategorije „Brodovi” (A - teretni brodovi, $B$ - brodovi za kružna putovanja, C - ratni brodovi i D - brodice) [23]

Images of cargo ships are collected from Google satellite images of ports: Rotterdam, Shanghai, Singapore, Trieste, Piraeus and Port Said and images of Suez and Panama channel. Images that are part of sub-class "Cruise ships" are collected from satellite images of French, Croatian, Spanish coast and from satellite images of Miami Beach. Images of war ships are collected by using satellite images of Naval Station Norfolk and Naval Base Pearl Harbor. Images of boats are collected from images of Croatian, French and Spanish coast. The "Other objects" main class is also divided into four sub-classes: "Waves", "Marine animals", "Garbage patches" and "Oil spills". Examples of these images are shown in Figure 2.

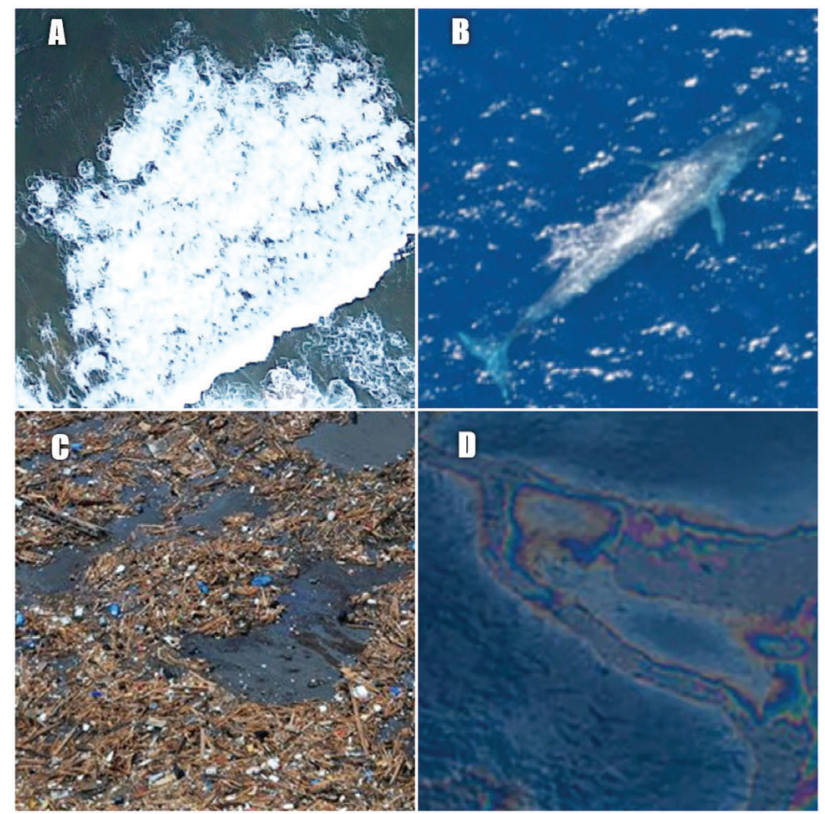

Figure 2 Examples of images that represent "Other objects" main class (A - Waves, B - Marine animals, C - Garbage patches, D - Oil spills) [23]

Slika 2. Primjeri slika osnovne kategorije "Ostali objekti" (A valovi, $B$ - morska bića, C - otoci smeća, D - izljevi nafte) [23] 
Images of waves are collected from Google satellite images of coasts of Portugal, California, Miami Beach, Chile and West Africa. Images of marine animals are collected by searching terms: "whales aerial images", "dolphins aerial images", "seals aerial images", "sea turtles aerial images" on Google Image Search. Images that are part of sub-class "Garbage patches" are collected by searching for term "garbage patches aerial image" on Google Image Search. By searching "oil spills aerial images", images of oil spills are collected. Obtained images are used for creating the dataset of 5608 images. This dataset is divided into two main sets and each main set is divided into four sub-sets, as shown in Table 1. The training dataset consists of 4000 images in total while testing dataset consists of 1608 images in total, respectively.

Table 1 Number of samples of every sub-set used for marine object detection algorithm training and testing

Tablica 1. Broj uzoraka svake potkategorije upotrijebljene za uvježbavanje i testiranje algoritma za otkrivanje morskih objekata

\begin{tabular}{|l|c|c|}
\multicolumn{1}{|c|}{ Class } & $\begin{array}{c}\text { Number of images } \\
\text { used for training }\end{array}$ & $\begin{array}{c}\text { Number of images used } \\
\text { for testing }\end{array}$ \\
\hline "Cargo ships" & 600 & 200 \\
\hline "Cruise ships" & 300 & 100 \\
\hline "War ships" & 300 & 100 \\
\hline "Boats" & 400 & 108 \\
\hline "Vessels" & 1600 & 508 \\
\hline "Waves" & 750 & 350 \\
\hline "Marine animals" & 150 & 50 \\
\hline "Garbage patches" & 750 & 350 \\
\hline "Oil spills" & 750 & 350 \\
\hline "Other objects" & 2400 & 1100 \\
\hline Total & 4000 & 1608 \\
\hline
\end{tabular}

\subsection{Algorithm description / Opis algoritma}

In this paper, an algorithm for marine objects recognition is proposed. This algorithm is based on CNN that is a variation of a neural network, mostly used in image recognition and computer vision applications [12] [19]. Structurally they are similar to multi-layer perceptron (MLP) in the sense that they consist of neurons which are organized into layers. The MLP and CNN consist of the input layer, hidden layers and the output layer. The main difference between these two types of artificial neural networks is in the type of layers used as hidden layers. In MLPs fully connected layers are used, while convolutional layers and pooling layers are used beside fully connected layers in the CNN [17][18]. The proposed algorithm for marine objects recognition consist of three CNNs in two stages. The CNN in the first stage is for object classification into two main classes: "Vessels" class and "Other objects" class. After object classification into two main classes, other two CNNs are utilized for sub-class recognition. One CNN in the second stage is utilized for recognition of subclasses in "Vessels" main class and other CNN is utilized for recognition of sub-classes in "Other objects" main class. Data flow diagram of the proposed algorithm for marine objects recognition is shown in Figure 3.

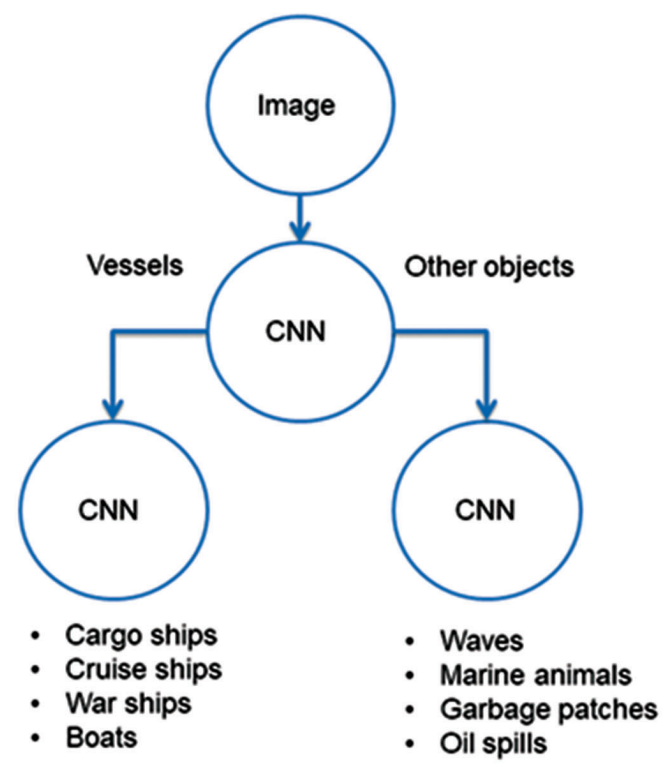

Figure 3 Data flow diagram of marine objects recognition algorithm

Slika 3. Dijagram tijeka podataka algoritma za prepoznavanje morskih objekata

\subsection{Research methodology / Metodologija}

For purposes of this research, 30 different CNN architectures are defined. These CNNs are designed by varying the number of convolutional layers, number of pooling layers, the number of fully connected layers and type of activation functions. CNN architectures that are utilized in this research are presented in Table 2.

Table 2 CNN architectures utilized for marine objects recognition

Tablica 2. CNN arhitekture upotrebljene za prepoznavanje morskih objekaa

\begin{tabular}{|c|c|c|c|}
\hline & $\begin{array}{c}\text { Number of } \\
\text { convolutional } \\
\text { layers }\end{array}$ & $\begin{array}{c}\text { Number of } \\
\text { pooling layers }\end{array}$ & Fully connected layers \\
\hline 1 & 1 & 1 & $\{1024\}$ \\
\hline 2 & 1 & 1 & $\{1024,512\}$ \\
\hline 3 & 2 & 2 & $\{1024\}$ \\
\hline 4 & 2 & 2 & $\{1024,512\}$ \\
\hline 5 & 3 & 3 & $\{1024\}$ \\
\hline 6 & 3 & 3 & $\{1024,512\}$ \\
\hline 7 & 4 & 4 & $\{1024,512\}$ \\
\hline 8 & 4 & 4 & $\{1024\}$ \\
\hline 9 & 5 & 5 & \\
\hline 10 & 5 & 5 & \\
\hline & & & \\
\hline
\end{tabular}

Convolutional layers are designed by combining $8 \times 8$ and $16 \times 16$ kernels. Pooling is performed by replacing a $2 \times 2$-pixel clusters with one pixel which have a value equal to maximal value of the pixel cluster. For designing fully connected layers Hyperbolic Tangent (Tanh), Logistic sigmoid and Rectified Linear Unit (ReLU) activation functions were used. For designing the output layer, Softmax activation function is utilized. Block scheme of proposed CNN is shown in Figure 4. The block scheme in Figure 4 corresponds to the architectures defined in Table 2 under 9 and 10. These architectures are representing CNNs designed with five convolutional and five pooling layers with variations in fully connected layers. 


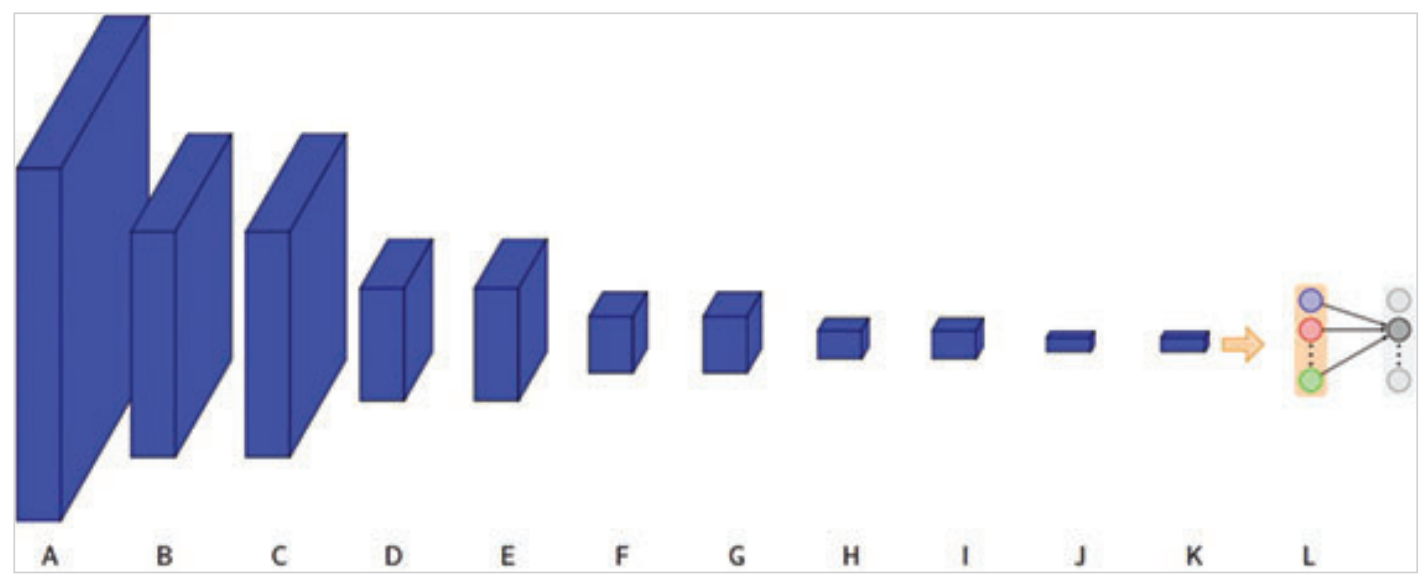

Figure 4 Block scheme of proposed CNN (A - Image, B - First convolutional layer (32 feature maps), C- First pooling layer (32 feature maps), D - Second convolutional layer (64 feature maps), E- Second pooling layer (64 feature maps), F - Third convolutional layer (128 feature maps), G - Third pooling layer (128 feature maps), H - Fourth convolutional layer ( 64 feature maps), I - Fourth pooling layer (64 feature maps), J - Fifth convolutional layer (32 feature maps), K - Fifth pooling layer (32 feature maps), L - Fully conected layers) Slika 4. Blok-dijagram predložene CNN mreže ( $A$ - slika, B-prvi konvolucijski sloj (32 karte značajki), C-prvi sloj sažimanja (32 karte značajki), $D$ - drugi konvolucijski sloj (64 karte značajki), E-drugi sloj sažimanja (64 karte značajki), F- treći konvolucijski sloj (128 karta značajki), G treći sloj sažimanja (128 karta značajki), H - četvrti konvolucijski sloj (64 karte značajki), I četvrti sloj sažimanja (64 karte značajki), J - peti konvolucijski sloj (32 karte značajki), K- peti sloj sažimanja (32 karte značajki), L- potpuno povezani slojevi)

For designing CNNs defined under 1 and 2 in Table 2 only layers marked with A, B, C and L are utilized. In these cases, CNNs are designed with one convolutional and one pooling layer. In cases 3 and 4, CNNs are designed with layers marked with $A$, $\mathrm{B}, \mathrm{C}, \mathrm{D}, \mathrm{E}$ and $\mathrm{L}$. CNNs marked with 5 and 6 are designed by utilizing three convolutional $(B, D, F)$ and three pooling $(C, E, G)$ layers. Finally, CNNs with architectures marked with 7 and 8 are designed with four convolutional $(B, D, F, H)$ and four pooling $(C, E, G, I)$ layers. Three CNNs which were used for designing the algorithm for marine object recognition were designed by using described variations.

CNNs are trained and tested by using datasets for training and testing. By using the test data set, recognition accuracy for each CNN was obtained. Using obtained results, maximal recognition accuracy is presented for cases of main classes and sub-classes recognition. For each main class and subclass, maximal accuracy achieved with each activation function utilized for designing fully connected layers are presented. Together with these accuracies, CNN architecture utilized for achieving maximal accuracy of each main class and sub-class recognition is presented.

\section{RESULTS AND DISCUSSION / Rezultati i rasprava}

First, the CNN for object classification in two main classes ("Vessels" and "Other objects") is trained and tested using entire dataset. From Figure 5, it can be seen that the maximal accuracy of object classification on vessels or other objects is higher than $91 \%$, regardless of activation function used for designing fully connected layers.

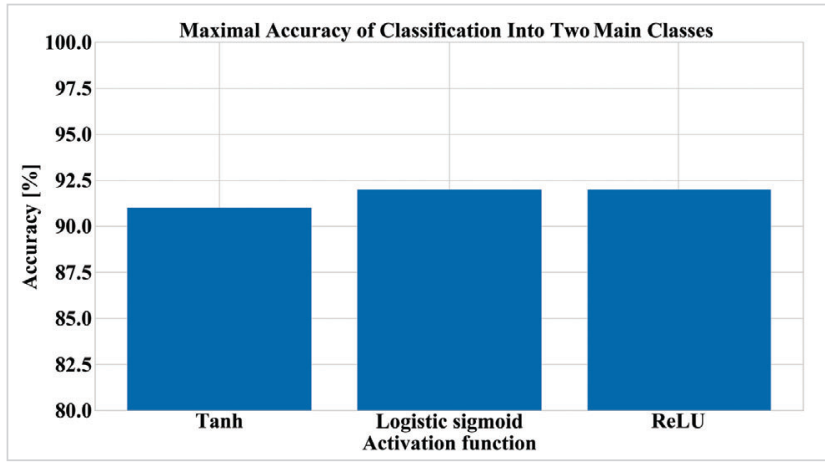

Figure 5 Maximal accuracy of classification into two main classes Slika 5. Maksimalna preciznost klasifikacije u dvjema osnovnim kategorijama

From obtained results it can be seen that maximal accuracy of $92.37 \%$ is achieved if CNN with three convolutional, three pooling and two fully connected layers is used. In this case, the highest accuracy is achieved if fully connected layers designed with Logistic sigmoid activation function are used, as shown in Table 3.

Table 3 CNN architecture with the highest accuracy of classification into two main classes

Tablica 3. CNN arhitektura s najvišom preciznošću klasifikacije u dvjema osnovnim kategorijama

\begin{tabular}{|c|c|c|c|c|}
$\begin{array}{c}\text { Number of } \\
\text { convolutional } \\
\text { layers }\end{array}$ & $\begin{array}{c}\text { Number } \\
\text { of pooling } \\
\text { layers }\end{array}$ & $\begin{array}{c}\text { Fully } \\
\text { connected } \\
\text { layers }\end{array}$ & $\begin{array}{c}\text { Activation } \\
\text { function }\end{array}$ & Accuracy \\
\hline 3 & 3 & 2 & $\begin{array}{c}\text { Logistic } \\
\text { sigmoid }\end{array}$ & $92.37 \%$ \\
\hline
\end{tabular}

After training and testing the CNN for classification into the two main classes, CNN for vessels classification is trained and tested using images from the "Vessels" main class. First, cargo ships recognition accuracy is observed. From obtained results it can be concluded that maximal accuracies higher than $90 \%$ will be achieved only if CNNs designed with ReLU or Tanh fully connected layers are utilized, as shown in Figure 6. 


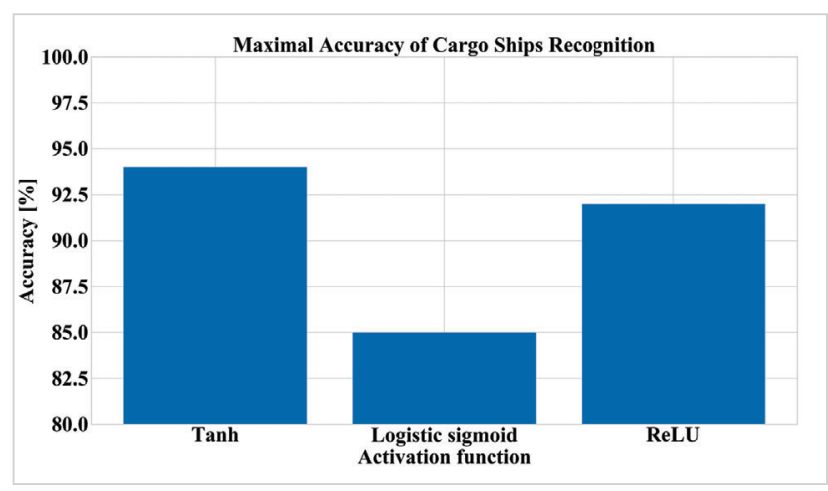

Figure 6 Maximal accuracy of cargo ships recognition for each activation function

Slika 6. Maksimalna preciznost prepoznavanja teretnih brodova za svaku aktivacijsku funkciju

The highest accuracy of cargo ships recognition will be achieved if $\mathrm{CNN}$ with three convolutional, three pooling and two fully connected layers designed with Tanh activation function is utilized, as shown in Table 4.

Table 4 CNN architecture with the highest accuracy of cargo ships recognition

Tablica 4. CNN arhitektura s najvišom preciznošću prepoznavanja teretnih brodova

\begin{tabular}{|c|c|c|c|c|}
\hline $\begin{array}{c}\text { Number of } \\
\text { convolutional } \\
\text { layers }\end{array}$ & $\begin{array}{c}\text { Number } \\
\text { of pooling } \\
\text { layers }\end{array}$ & $\begin{array}{c}\text { Fully } \\
\text { connected } \\
\text { layers }\end{array}$ & $\begin{array}{c}\text { Activation } \\
\text { function }\end{array}$ & Accuracy \\
\hline 3 & 3 & 2 & Tanh & $94.12 \%$ \\
\hline
\end{tabular}

If the accuracy of cruise ships recognition is observed, it can be concluded that maximal accuracies higher than $95 \%$ will be achieved if CNNs designed with Tanh or ReLU activation functions are utilized. CNN designed with Logistic sigmoid activation function achieves the maximal accuracy higher than $93 \%$, Figure 7.

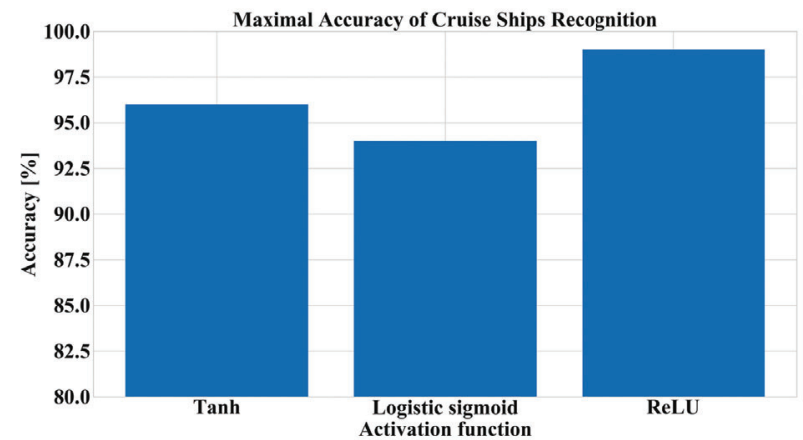

Figure 7 Maximal accuracy of cruise ships recognition for each activation function

Slika 7. Maksimalna preciznost prepoznavanja brodova za kružna putovanja za svaku aktivacijsku funkciju

The highest accuracy of $98.82 \%$ will be achieved if CNN with five convolutional, five pooling and three fully connected layers designed with ReLU activation function is utilized, as shown in Table 5.
Table 5 CNN architecture with the highest accuracy of cruise ships recognition

Tablica 5. CNN arhitektura s najvišom preciznošću prepoznavanja brodova za kružna putovanja

\begin{tabular}{|c|c|c|c|c|}
$\begin{array}{c}\text { Number of } \\
\text { convolutional } \\
\text { layers }\end{array}$ & $\begin{array}{c}\text { Number } \\
\text { of pooling } \\
\text { layers }\end{array}$ & $\begin{array}{c}\text { Fully } \\
\text { connected } \\
\text { layers }\end{array}$ & $\begin{array}{c}\text { Activation } \\
\text { function }\end{array}$ & Accuracy \\
\hline 5 & 5 & 3 & ReLU & $98.82 \%$ \\
\hline
\end{tabular}

Recognition of war ships will achieve maximal accuracies higher than $95 \%$ if CNNs designed with Tanh or ReLU activation functions were used, similar to the case of cruise ships recognition. If CNN designed with Logistic sigmoid activation function is utilized, the maximal accuracy of $93 \%$ will be achieved, as shown in Figure 8.

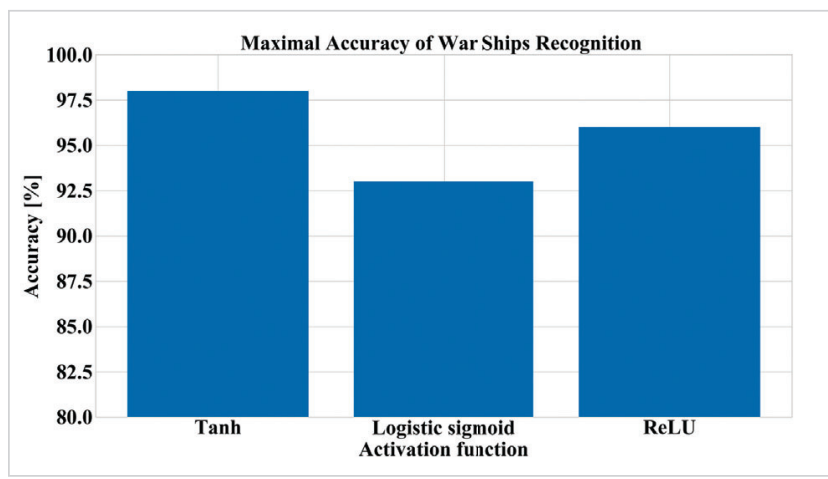

Figure 8 Maximal accuracy of war ships recognition for each activation function

Slika 8. Maksimalna preciznost prepoznavanja ratnih brodova za svaku aktivacijsku funkciju

The highest accuracy of war ships recognition (97.64\%) will be achieved if CNN with two convolutional, two pooling and two fully connected layers designed with Tanh activation function is utilized, as shown in Table 6.

Table 6 CNN architecture with the highest accuracy of war ships recognition

Tablica 6. CNN arhitektura s najvišom preciznošću prepoznavanja ratnih brodova

\begin{tabular}{|c|c|c|c|c|}
\hline $\begin{array}{c}\text { Number of } \\
\text { convolutional } \\
\text { layers }\end{array}$ & $\begin{array}{c}\text { Number } \\
\text { of pooling } \\
\text { layers }\end{array}$ & $\begin{array}{c}\text { Fully } \\
\text { connected } \\
\text { layers }\end{array}$ & $\begin{array}{c}\text { Activation } \\
\text { function }\end{array}$ & Accuracy \\
\hline 2 & 2 & 2 & Tanh & $97.64 \%$ \\
\hline
\end{tabular}

The maximal accuracy of boats recognition will be higher than $93 \%$, regardless of activation function utilized for designing fully connected layers, as shown in Figure 9. 


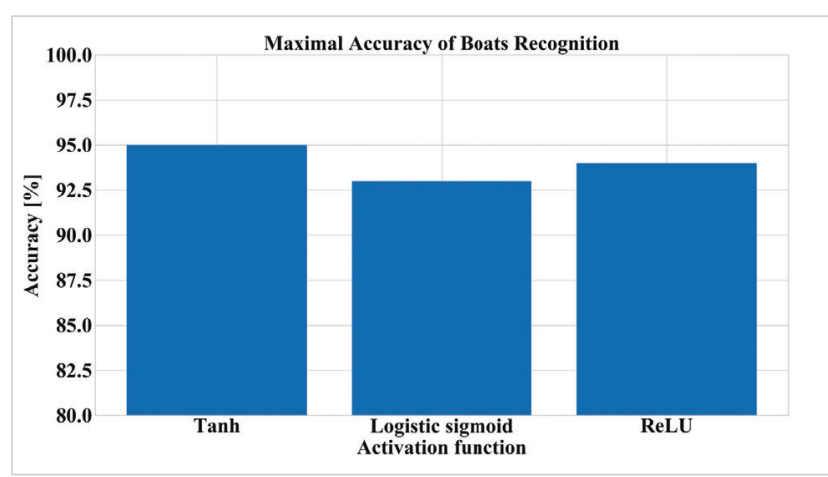

Figure 9 Maximal accuracy of boats recognition for each activation function

Slika 9. Maksimalna preciznost prepoznavanja brodica za svaku aktivacijsku funkciju

The CNN architecture that achieves the highest accuracy is presented in Table 7. It can be concluded that the highest accuracy is, again, achieved if Tanh activation function is utilized for the design of two fully connected layers. CNN with the highest accuracy is designed by using three convolutional and three pooling layers.

Table 7 CNN architecture with the highest accuracy of boats recognition

Tablica 7. CNN arhitektura s najvišom preciznošću prepoznavanja brodica

\begin{tabular}{|c|c|c|c|c|}
\hline $\begin{array}{c}\text { Number of } \\
\text { convolutional } \\
\text { layers }\end{array}$ & $\begin{array}{l}\text { Number } \\
\text { of pooling } \\
\text { layers }\end{array}$ & $\begin{array}{l}\text { Fully } \\
\text { connected } \\
\text { layers }\end{array}$ & $\begin{array}{l}\text { Activation } \\
\text { function }\end{array}$ & Accuracy \\
\hline 3 & 3 & 2 & Tanh & $95.29 \%$ \\
\hline
\end{tabular}

When CNN for recognition of "Other objects" main class is trained and tested, it can be concluded that CNN cannot recognize waves with the maximal accuracy higher of $90 \%$ regardless of activation function utilized, as shown in Figure 10.

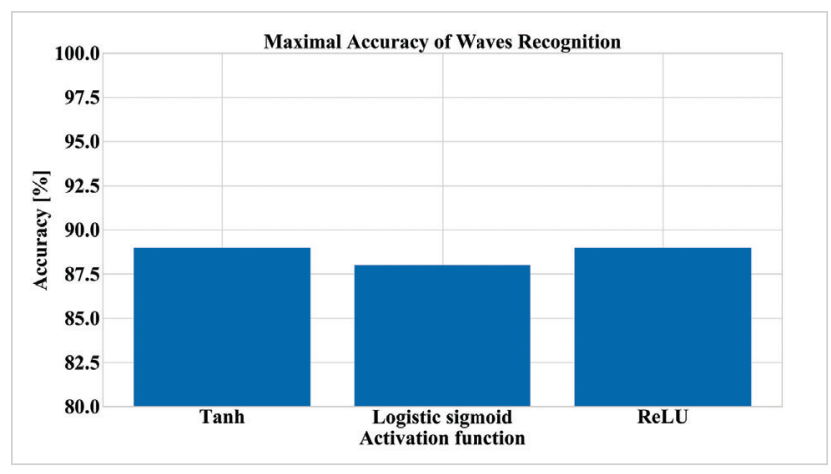

Figure 10 Maximal accuracy of waves recognition for each activation function

Slika 10. Maksimalna preciznost prepoznavanja valova za svaku aktivacijsku funkciju

The CNN architecture utilized for achieving the highest accuracy is presented in Table 8. It can be seen that the maximal accuracy is achieved if CNN is designed by combining three convolutional, three pooling and three fully connected layers. The maximal accuracy will be achieved if fully connected layers are designed by using Tanh activation function.

Table $8 \mathrm{CNN}$ architecture with the highest accuracy of waves recognition

Tablica 8. CNN arhitektura s najvišom preciznošću prepoznavanja valova

\begin{tabular}{|c|c|c|c|c|}
$\begin{array}{c}\text { Number of } \\
\text { convolutional } \\
\text { layers }\end{array}$ & $\begin{array}{c}\text { Number } \\
\text { of pooling } \\
\text { layers }\end{array}$ & $\begin{array}{c}\text { Fully } \\
\text { connected } \\
\text { layers }\end{array}$ & $\begin{array}{c}\text { Activation } \\
\text { function }\end{array}$ & Accuracy \\
\hline 3 & 3 & 3 & Tanh & $88.56 \%$ \\
\hline
\end{tabular}

As in the case of waves recognition, maximal accuracy of marine animals recognition does not exceed $90 \%$, regardless of activation function utilized, Figure 11.

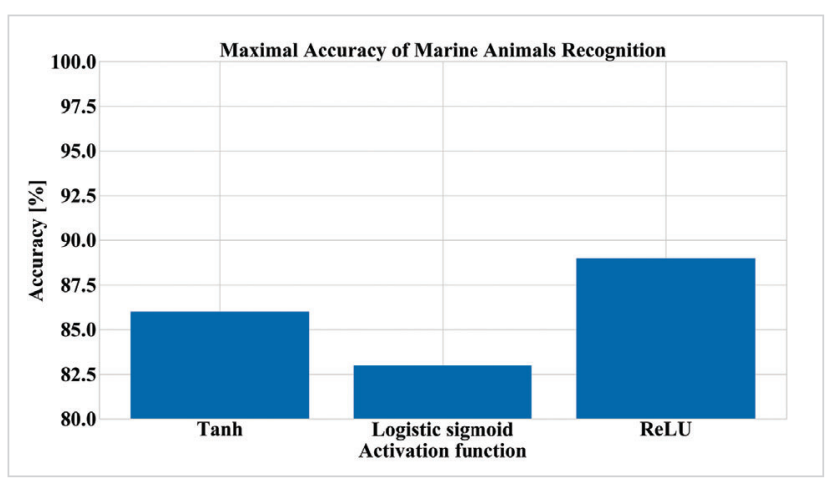

Figure 11 Maximal accuracy of marine animals recognition for each activation function

Slika 11. Maksimalna preciznost prepoznavanja morskih bića za svaku aktivacijsku funkciju

The highest accuracy of marine animals recognition will be achieved if CNN architecture with three convolutional, three pooling and two fully connected layers is utilized. For designing this CNN, ReLU activation function is used, Table 9.

Table 9 CNN architecture with the highest accuracy of marine animals recognition

Tablica 9. CNN arhitektura s najvišom preciznošću prepoznavanja morskih bića

\begin{tabular}{|c|c|c|c|c|}
$\begin{array}{c}\text { Number of } \\
\text { convolutional } \\
\text { layers }\end{array}$ & $\begin{array}{c}\text { Number } \\
\text { of pooling } \\
\text { layers }\end{array}$ & $\begin{array}{c}\text { Fully } \\
\text { connected } \\
\text { layers }\end{array}$ & $\begin{array}{c}\text { Activation } \\
\text { function }\end{array}$ & Accuracy \\
\hline 3 & 3 & 2 & ReLU & $88.56 \%$ \\
\hline
\end{tabular}

In the case of garbage patches detection, the maximal accuracy is considerably higher, and it exceeds $93 \%$ regardless of activation function utilized, as presented in Figure 12. When Tanh or ReLU activation functions are used for designing fully connected layers, CNNs are achieving maximal accuracies higher than $96 \%$, what represents a significant increase in the maximal accuracy when compared to the detection of waves or marine animals. 


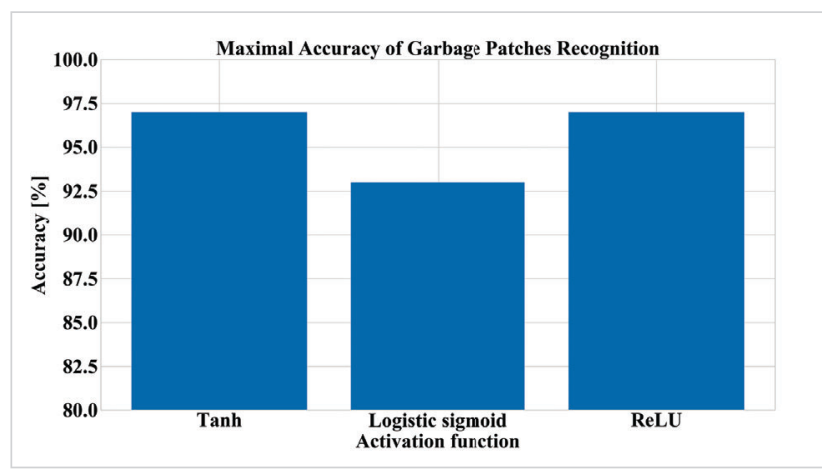

Figure 12 Maximal accuracy of garbage patches recognition for each activation function

Slika 12. Maksimalna preciznost prepoznavanja otoka smeća za svaku aktivacijsku funkciju

The highest accuracy of garbage patches recognition is achieved if CNN designed with two convolutional, two pooling and three fully connected layers is utilized. In this case, fully connected layers are designed by using the ReLU activation function, as shown in Table 10.

Table 10 CNN architecture with the highest accuracy of garbage patches recognition

Tablica 10. CNN arhitektura s najvišom preciznošću prepoznavanja otoka smeća

\begin{tabular}{|c|c|c|c|c|}
$\begin{array}{c}\text { Number of } \\
\text { convolutional } \\
\text { layers }\end{array}$ & $\begin{array}{c}\text { Number } \\
\text { of pooling } \\
\text { layers }\end{array}$ & $\begin{array}{c}\text { Fully } \\
\text { connected } \\
\text { layers }\end{array}$ & $\begin{array}{c}\text { Activation } \\
\text { function }\end{array}$ & Accuracy \\
\hline 2 & 2 & 3 & ReLU & $96.92 \%$ \\
\hline
\end{tabular}

Same as in the case of waves or marine animals recognition, in the case of oil spills recognition maximal accuracies are not exceeding 90\%, as shown in Figure 13.

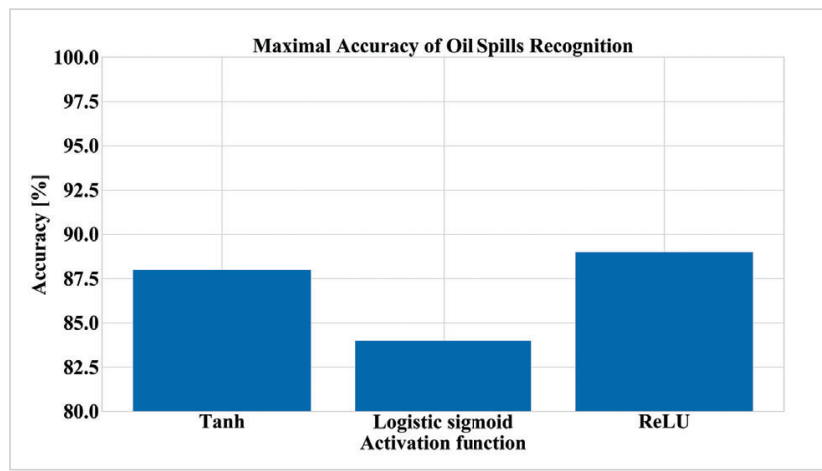

Figure 13 Maximal accuracy of oil spills recognition for each activation function

Slika 13. Maksimalna preciznost prepoznavanja izljeva nafte za svaku aktivacijsku funkciju

The highest accuracy is achieved if CNN with three convolutional, three pooling and three fully connected layers designed with ReLU activation function is utilized, as shown in Table 11.
Table 11 CNN architecture with the highest accuracy of oil spills recognition

Tablica 11. CNN arhitektura s najvišom preciznošću prepoznavanja izljeva nafte

\begin{tabular}{|c|c|c|c|c|}
$\begin{array}{c}\text { Number of } \\
\text { convolutional } \\
\text { layers }\end{array}$ & $\begin{array}{c}\text { Number } \\
\text { of pooling } \\
\text { layers }\end{array}$ & $\begin{array}{c}\text { Fully } \\
\text { connected } \\
\text { layers }\end{array}$ & $\begin{array}{c}\text { Activation } \\
\text { function }\end{array}$ & Accuracy \\
\hline 3 & 3 & 3 & ReLU & $89.21 \%$ \\
\hline
\end{tabular}

\section{CONCLUSION / Zaključak}

In this paper a CNN-based approach for marine object recognition is presented. From obtained results, it can be seen that accuracies higher than $88 \%$ are achieved if appropriate $\mathrm{CNN}$ architecture is utilized. According to obtained results, three conclusions can be drawn.

- CNN is an appropriate algorithm for marine objects recognition from aerial images.

- CNN-based algorithm can be used for recognizing vessel type, marine animals, waves and pollution.

- Universal CNN-based algorithm for marine objects recognition and classification can be utilized.

The described approach is offering stable object recognition performances. According to obtained results it can be concluded that is possible to utilize more than one CNN architecture for each object recognition. This property allows integration of redundant CNNs into the algorithm structure.

\section{ACKNOWLEDGMENT / Zahvala}

This research has been (partly) supported by the CEEPUS network CIII-HR-0108, European Regional Development Fund under the grant KK.01.1.1.01.0009 (DATACROSS) and University of Rijeka scientific grant uniri-tehnic-18-275-1447.

\section{REFERENCES / Literatura}

[1] Ding, G., Wu, Q., Zhang, L., Lin, Y., Tsiftsis, T. A., Yao, Y. D. (2018). "An amateur drone surveillance system based on the cognitive Internet of Things". IEEE Communications Magazine, Vol. 56, No. 1, pp. 29-35. https://doi.org/10.1109/ mcom.2017.1700452

[2] Boudjit, K., Larbes, C. (July 2015).“Detection and implementation autonomous target tracking with a Quadrotor AR. Drone". 12th International Conference on Informatics in Control, Automation and Robotics (ICINCO), Vol. 2, pp. 223-230. https://doi.org/10.5220/0005523102230230

[3] Voigt, S., Kemper, T., Riedlinger, T., Kiefl, R., Scholte, K., Mehl, H. (2007). “Satellite image analysis for disaster and 3-management support". IEEE transactions on geoscience and remote sensing, Vol. 45, No. 6, pp. 1520-1528. https://doi. org/10.1109/tgrs.2007.895830

[4] Hirata, M., Kogab, N., Shinjo, H., Fujita, H., Gintzburger, G., Miyazaki, A. (2001). "4 classification by satellite image processing in a dry area of north-eastern Syria". International Journal of Remote Sensing, Vol. 22, No. 4, pp. 507-516. https://doi.org/10.1080/01431160050505829

[5] Kolarić, A. (2011). "Utjecaj antropogenih čimbenika na smrtnost kitova (Cetacea) u Jadranskom moru". Veterinar, Vol. 49, No. 1, pp. 5-15.

[6] Karamanlidis, A. A., Androukaki, E., Adamantopoulou, S., Chatzispyrou, A., Johnson, W. M., Kotomatas, S., Tounta, E. (2008). "Assessing accidental entanglement as a threat to the Mediterranean monk seal Monachus monachus". Endangered Species Research, Vol. 5, No. 2-3, pp. 205-213. https:// doi.org/10.3354/esr00092

[7] Bukovac, O., Medica, V., Mrzljak, V. (2015). “Steady state performances analysis of modern marine two-stroke low speed diesel engine using MLP neural network model". Shipbuilding: Theory and Practice of Naval Architecture, Marine Engineering and Ocean Engineering, Vol. 66, No. 4, pp. 57-70.

[8] Orović, J., Mrzljak, V., Poljak, I. (2018). “Efficiency and Losses Analysis of Steam Air Heater from Marine Steam Propulsion Plant". Energies, Vol. 11, No. 11, p. 3019. https://doi.org/10.3390/en11113019 
[9] Mrzljak, V., Poljak, I., Medica-Viola, V. (2017). "Dual fuel consumption and efficiency of marine steam generators for the propulsion of LNG carrier". Applied Thermal Engineering, Vol. 119, pp. 331-346. https://doi.org/10.1016/j. applthermaleng.2017.03.078

[10] Mrzljak, V., Poljak, I., Mrakovčić, T. (2017). “Energy and exergy analysis of the turbo-generators and steam turbine for the main feed water pump drive on LNG carrier". Energy Conversion and Management, Vol. 140, pp. 307-323. https://doi.org/10.1016/j.enconman.2017.03.007

[11] Qiang, Z., Guibing, Z., Xin, H., Renming, Y. (2019). “Adaptive neural network auto-berthing control of marine ships". Ocean Engineering, Vol. 177, pp. 40-48. https://doi.org/10.1016/j.oceaneng.2019.02.031

[12] Simonyan, K., Zisserman, A. (2014). "Very deep convolutional networks for large-scale image recognition". arXiv preprint arXiv:1409.1556. DOI: https:// doi.org/10.14257/astl.2016.140.36

[13] Cireşan, D., Meier, U., Schmidhuber, J. (2012). "Multi-column deep neural networks for image classification". arXiv preprint arXiv:1202.2745. https://doi. org/10.1109/cvpr.2012.6248110

[14] Sokolov, I., Dokukin, M. E., Kalaparthi, V., Miljkovic, M., Wang, A., Seigne, J. D., Grivas, P., Demidenko, E. (2018). "Noninvasive diagnostic imaging using machine-learning analysis of nanoresolution images of cell surfaces: Detection of bladder cancer". Proceedings of the National Academy of Sciences, Vol. 115, No. 51, pp. 12920-12925. https://doi.org/10.1073/pnas.1816459115

[15] Bogović, K., Lorencin, I., Anđelić, N., Blažević, S., Smolčić, K., Španjol, J., Car, Z. (January 2018). "Artificial intelligence-based method for urinary bladder cancer diagnostic". International Conference on Innovative Technologies, INTECH 2018, pp. 51-53.
[16] Aksoy, S., Akçay, H. G., Wassenaar, T. (2010). "Automatic mapping of linear woody 4 features in agricultural landscapes using very high resolution imagery". IEEE Transactions on Geoscience and Remote Sensing, Vol. 48, No. 1 pp. 511-522. https://doi.org/10.1109/tgrs.2009.2027702

[17] Bargoti, S., Underwood, J. (May 2017). "Deep fruit detection in orchards". 2017 IEEE International Conference on Robotics and Automation (ICRA), pp. 36263633. https://doi.org/10.1109/icra.2017.7989417

[18] Houben, S., Stallkamp, J., Salmen, J., Schlipsing, M., Igel, C. (August 2013) "Detection of traffic signs in real-world images: The German Traffic Sign Detection Benchmark". The 2013 international joint conference on neural networks (IJCNN), pp. 1-8. https://doi.org/10.1109/ijcnn.2013.6706807

[19] Franke, U., Heinrich, S. (2002). "Fast obstacle detection for urban traffic situations". IEEE Transactions on Intelligent Transportation Systems, Vol. 3, No. 3, 173-181. https://doi.org/10.1109/tits.2002.802934

[20] Bentes, C., Velotto, D., Tings, B. (2017). "Ship classification in terrasar-x images with convolutional neural networks". IEEE Journal of Oceanic Engineering, Vol. 43, No. 1, pp. 258-266. https://doi.org/10.1109/joe.2017.2767106

[21] Liu, Y., Zhang, M. H., Xu, P., Guo, Z. W. (May 2017). "SAR ship detection using sealand segmentation-based convolutional neural network". 2017 International Workshop on Remote Sensing with Intelligent Processing (RSIP), pp. 1-4. https:// doi.org/10.1109/rsip.2017.7958806

[22] Lu, H., Li, Y., Uemura, T., Ge, Z., Xu, X., He, L., Kim, H. (2018). “FDCNet: filtering deep convolutional network for marine organism classification". Multimedia tools and applications, Vol. 77, No. 17, pp. 21847-21860. https://doi. org/10.1007/s11042-017-4585-1

[23] https://www.google.com/maps [accessed: 6/1/2019] 